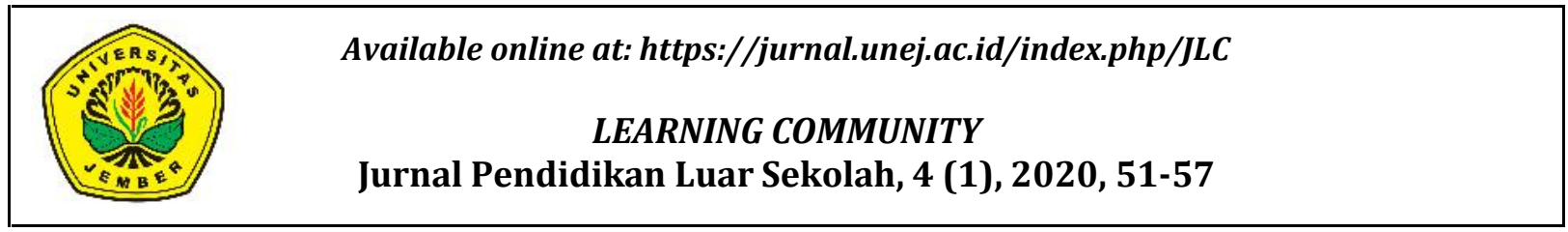

\title{
Program Kewirausahaan Pada Kemandirian Warga Belajar Kelompok Belajar Paket C
}

\author{
Frimha Purnamawati ${ }^{1}$ \\ ${ }^{1}$ Pendidikan Luar Sekolah, Universitas Jember. Jl. Kalimantan No. 37, Tegal Boto, Jember 62811, Indonesia \\ Email: frimha.fkip@unej.ac.id, Telp: +6282244033908
}

\begin{abstract}
Abstrak
Kewirausahaan diharapkan dapat menumbuhkan sikap kemandirian warga belajar sehingga dapat menerima kemajuan di era globalisasi ini, tidak mempunyai pola pikir pengikut dan dapat menciptakan lapangan pekerjaan sendiri serta membantu warga belajar yang lain agar berdaya guna. Metode pengumpulan data yang digunakan adalah metode wawancara, observasi dan dokumentasi. Dari hasil penelitian tersebut menunjukkan bahwa ada perubahan perilaku kemandirian pada warga belajar kelompok belajar paket C di PKBM Al-Hikmah Sukodono Sidoarjo yaitu munculnya sikap mandiri warga belajar dalam membuka usaha sendiri serta meningkatkan kualitas pekerjaannya.
\end{abstract}

Kata Kunci: kewirausahaan, kemandirian, Paket C

\section{The Entrepreneurship Program on the Independence of Package $C$ Learning Group}

\begin{abstract}
Entrepreneurship is expected to foster an attitude of independence of learning citizens so they can accept progress in this era of globalization, do not have a mindset of followers and can create their own jobs and help other learning citizens to be efficient. Data collection methods used are interviews, observation and documentation. From the results of this study indicate that there is a change in the behavior of independence in the learning group learning group $C$ package at PKBM Al-Hikmah Sukodono Sidoarjo namely the emergence of an independent attitude of learning citizens in opening their own businesses and improving the quality of their work.
\end{abstract}

Keywords: Entrepreneurship, independence, Package C 


\section{Learning Community: Jurnal Pendidikan Luar Sekolah, 4 (1), Maret 2020 - 52}

Frimha Purnamawati

\section{PENDAHULUAN}

Pendidikan Keseteraan merupakan pendidikan non formal yang ditujukan bagi masyarakat yang karena sesuatu hal tidak berkesempatan mengikuti pendidikan pada jalur formal. Pendidikan Kesetaraan sendiri dibagi menjadi tiga yaitu Paket A setara SD/MI, Paket B setara SMP, dan Paket C setara SMA. Pendidikan Kesetaraan memiliki Standar Kompetensi Lulusan (SKL) yang sama dengan formal dan memiliki kekhasan didalamnya yang terbagi menjadi (1) Paket A yaitu Memiliki keterampilan dasar untuk memenuhi kebutuhan hidup sehari-hari, (2) Paket B yaitu memiliki keterampilan untuk memenuhi tuntutan dunia kerja dan (3) Paket C yaitu memiliki keterampilan berwirausaha (Permendiknas No. 23/2006).

Kebutuhan akan peningkatan penguasaan ilmu dan teknologi pada masa sekarang semakin dirasakan seiring dengan semakin meluas dan semakin rasionalnya hubungan-hubungan manusia dalam tatanan global masyarakat modern. Fenomena ini paling tidak dapat didekati dari kecenderungan tiga elemen penting, yaitu bahwa : (1) individu -individu semakin membutuhkan wawasan-wawasan dan penguasaan keterampilan - keterampilan baru atau tambahan bagi penyesuaian dengan tuntutan dunia kerja, peningkatan karier, atau aktualisasi diri dimasyarakat; (2) organisasi-organisasi usaha maupun organisasi-organisasi sosial memandang perlu dan mendesak untuk memiliki sumber daya manusia yang mampu mengembangkan strategi operasi yang dapat diandalkan dalam iklim usaha yang semakin kompetitif; dan (3) pemerintah sangat berkepentingan dengan upaya-upaya memajukan kesejahteraan sosial lewat pengembangan potensi insan pada lingkup mikro organisasi maupun lingkup makro masyarakat. (Kamil 2010:5).

Pencapaian dari warga belajar paket C dipersiapkan guna menghadapi tantangan globalisasi, mengurangi pengangguran dan dapat menciptakan lapangan pekerjaan bagi warga belajar yang lain adalah berwirausaha. Keberanian, keutamaan serta keperkasaan dalam memenuhi kebutuhan serta memecahkan permasalahan hidup dengan kekuatan yang ada pada diri sendiri (Wasty Soemanto, 1984:
43). "Enterprenuer as the person who destroys the existing economic order by introducing new product and services, by creating new forms of organization, or by exploiting new raw materials.(Bygrave, 1994: 1). Adapun salah satu tujuan dari kewirausahaan adalah mencapai tujuan yang dikehendaki sendiri, mendemonstrasikan kemampuan serta potensi seseorang secara penuh, memperoleh manfaat dan keuntungan secara maksimal, membantu masyarakat dengan usaha-usaha konkrit melalui program keterampilan yang diarahkan pada kewirausahaan dan diharapkan mereka mampu memanfaatkan potensi ekonomyi lingkungannya untuk usaha mandiri baik secara individu maupun kelompok serta perubahan perilaku kemandirian dalam hal ini merupakan karakteristik individu sehingga mampu membuat keputusan sendiri setelah secara masak dan konsekuen mampu mensistemkan dan mensinergikan lingkungannya secara baik.

\section{METODE}

Dalam penelitian yang dimaksud ini adalah jenis penelitian dengan pendekatan kualitatif. Bodgan dan Taylor (1975:5) mendefinisikan Metodologi kualitatif sebagai prosedur penelitian yang menghasilkan data deskriptif berupa kata-kata tertulis atau lisan dari orang-orang dan perilaku yang dapat diamati. Subyek penelitian merupakan subyek yang menjadi sasaran penelitian dapat dijadikan sebagai sumber data (Arikunto, 2002: 103). Subyek dalam penelitian ini adalah warga belajar paket $C$ Kelas XII di PKBM Al-Hikmah Sukodono dengan jumlah 20 orang. Teknik pengumpulan data dalam penelitian ini adalah menggunakan metode wawancara, observasi, dan dokumentasi.

\section{Wawancara (Interview)}

Wawancara (interview) adalah percakapan dengan maksud tertentu yang dilakukan oleh dua pihak, yaitu pewancara (peneliti) yang mengajukan pertanyaan dan yang diwawancarai (subyek peneliti) yang memberikan jawaban atas pertanyaan itu (Moleong, 2005:135). Dalam metode wawancara (interview) menggunakan instrumn pedoman wawancara atau dapat juga menggunakan check list (Arikunto, 
2006:155). Data yang dikumpulkan melalui wawancara (interview) meliputi :
a. Warga
Belajar
Paket
tanggapan mengenai kegiatan
kewirausahaan, aktifitas dalam
kegiatan kewirausahaan serta
manfaat warga belajar setelah mengikuti program kewirausahaan.

b. Pendamping, tanggapan mengenai warga belajar paket $\mathrm{C}$ dalam kegiatan kewirausahaan, perubahan setelah mengikuti kegiatan kewirausahaan (warga belajar Paket $\mathrm{C}$ yang dibina) serta kendala yang dihadapi dalam perubahan perilaku kemandirian warga belajar paket $\mathrm{C}$ melalui kewirausahaan.

c. Ketua Penyelenggara Program, program kewirausahaan yang dilaksanakan, sarana pengelolaan dan kendala yang dihadapi dalam perubahan perilaku kemandirian warga belajar paket C.

2. Pengamatan (Observasi)

Metode observasi adalah metode pengumpulan data yang menggunakan pengamatan terhadap obyek penelitian (Riyanto, 2001: 96). Metode observasi adalah sebagai kegiatan pemusatan perhatian terhadap obyek dengan menggunakan seluruh alat indera. (Arikunto, 2006:156)

Berdasarkan

keterlibatan pengamatan dalam kegiatan orang-orang yang diamati maka observasi dibedakan menjadi dua yaitu:

a. Observasi partisipasi adalah merupakan observasi dimana pengamat ikut serta dalam kegiatan yang mereka lakukan oleh subyek yang mereka teliti atau yang diamati seolah-olah merupakan bagian dari mereka.

b. Observasi partisipan merupakan observasi dimana pengamat berada diluar subyek yang diteliti dan ikut dalam kegiatan yang mereka lakukan. Dalam penggunaan metode observasi peneliti dapat menggali data tentang :
1) kegiatan sumber belajar dalam kegiatan di tempat latihan yang dilaksanakan
2) aktifitas dalam proses program kewirausahaan

3) jumlah peserta didik yang mengikuti kegiatan program kewirausahaan

\section{Dokumentasi}

Metode dokumentasi yaitu mencari data mengenai hal-hal atau variabel yang berupa catatan transkrip, buku surat kabar, majalah, notulen, rapat agenda, dan sebagainya (Arikunto, 2006:158).

Metode dokumentasi berarti cara mengumpulkan data dengan mencatat data-data yang sudah ada (Riyanto, 2001:103). Dalam peneletian ini dimaksudkan untuk mempelajari dokumen-dokumen, foto-foto dan kegiatan yang sudah dilakukan sebelumnya.

Dalam penelitian ini peneliti mengumpulkan data-data tentang:

a. Data Warga Belajar (Paket C)

b. Sejarah berdirinya Instansi, dan Program kewirausahaan.

c. Data Sumber belajar

d. Data jurnal kegiatan sumber belajar

Teknik Analisis Data dalam penelitian ini analisis data kualitatif menurut Miles and Huberman dilakukan secara interaktif melalui proses data reduction, data display dan verification. Uji keabsahan data meliputi uji kredibilitas data (validitas internal), uji depenabilitas (reliabilitas) data, dan uji komfirmabilitas (obyektivitas).

\section{HASIL DAN PEMBAHASAN}

Berdasarkan dari hasil penelitian yang sudah dianalisis bahwa dampak program kewirausahaan terhadap perubahan perilaku kemandirian warga belajar kelompok belajar paket C di PKBM Al-Hikmah Sukodono Sidoarjo yang juga merupakan program dibawah binaan yayasan Al-Hikmah Sukodono Sidoarjo mempunyai manfaat sendiri serta membuka akses komunikasi lewat Pendidikan Luar Sekolah (PLS) untuk mengembangkan sumber daya manusia yang produktif di masa sekarang ini. Hal ini tercermin di dalam hasil analisis data yang diperoleh dalam penelitian ini yaitu bahwa program kewirausahaan ini di kelola oleh H.Makali Hari Santoso, S.Pd selaku ketua penyelenggara PKBM dan program kewirausahaan. 


\title{
Learning Community: Jurnal Pendidikan Luar Sekolah, 4 (1), Maret 2020 - 54
}

\author{
Frimha Purnamawati
}

Warga belajar yang mengikuti kegiatan program kewirausahaan terhadap perubahan perilaku kemandirian di PKBM Al-Hikmah Sukodono Sidoarjo berjumlah 20 orang secara keseluruhan yang berminat mengikuti baik program kewirausahaan pra koperasi maupun program kewirausahaan berbasis life skill dan mereka mempunyai latar belakang yang berbeda-beda. Ditinjau dari segi usia 17-25 tahun ke atas dengan pendidikan akhir sekolah menengah pertama (SMP) dan saat ini sedang mengikuti program kesetaraan paket C di PKBM Al-Hikmah Sukodono Sidoarjo. Karena dalam program ini yang menjadi tuntutan adalah adanya perubahan perilaku kemandirian pada warga belajar kelompok belajar paket $\mathrm{C}$ maka program ini diberikan kepada warga belajar baik laki-laki maupun perempuan sehingga warga belajar yang mengikuti program ini dapat meningkatkan pengetahuan bagaimana cara berwirausaha dan keterampilan yang sesuai dengan bakat dan minatnya yang sudah di fasilitasi oleh pihak PKBM Al- Hikmah Sukodono Sidoarjo. Dan diharapkan warga belajar selanjutnya dapat mandiri dengan membuka usaha sendiri atau meningkatnya status pekerjaan yang awalnya buruh menjadi karyawan seperti pada warga belajar angkatan 1 yang sudah berhasil.

Dari sedikit ulasan mengenai analisis data yang sudah diuaraikan diatas maka peneliti dapat menyimpulkan bahwa dampak program kewirausahaan terhadap perubahan perilaku kemandirian sangat berpengaruh besar. Karena dengan mengikuti program ini setiap warga belajar merasakan bahwa ada perubahan perilaku kemandirian, meningkatnya etos kerja, keterampilan, pendapatan dan kesejahteraan warga belajar paket C. Faktor pendukung adalah letak strategis, dalam penelitian ini letaknya di PKBM Al-Hikmah Sukodono Sidoarjo di Jalan Raya Sukodono No. 3 Sukodono Sidoarjo sehingga dapat mempermudah masuknya inovasi teknologi. Dengan nama besar yayasan Al-Hikmah Program Kewirausahaan dapat mudah dikenal masyarakat umum, khususnya buruh pabrik di lingkungan sekitar PKBM AlHikmah Sukodono Sidoarjo. Adanya kemauan keras dari warga belajar khususnya kelompok belajar paket $\mathrm{C}$ sendiri untuk ikut dan aktif dalam mengikuti pelaksanaan program ini. Ketelatenan nara sumber/ tutor dalam membelajarkan atau membimbing warga belajar. Sarana dan prasarana yang memadai dan nyaman seperti halnya tempat yang strategis serta adanya koordinasi para nara sumber/ tutor dan warga belajar sehingga dapat menunjang keberhasilan proses pembelajaran dikarenakan program ini teraplikasi dengan program pembelajaran kesetaraan. Adanya dukungan intensif dari masyarakat dan pemerintah. Tersedianya dana dalam mengelola program ini dan tersedianya tenaga produktif sebagai sasaran pelaksanaan program.

Faktor penghambat dalam program kewirausahaan ini adalah Pengemasan produk hasil menjahit masih bersifat alami, Warga belajar masih belum bisa melakukan promosi, Administrasi Kewirausahaan masih bersifat individu atau masih sesuai dengan keinginan warga belajar. Kurangnya warga belajar dalam pelaksanaan program (lebih pada faktor cuaca) jika cuaca hujan warga belajar banyak yang tidak mengikuti program kewirausahaan sedangkan cuaca terang warga belajar banyak yang mengikuti program kewirausahaan. Waktu kerja warga belajar kelompok belajar paket $\mathrm{C}$ terkadang sering berbenturan dengan waktu dalam proses program kewirausahaan. Pelaksanaan Program Kewirausahaan hanya dilakukan pada hari Rabu Pukul 19.00 - 21.00 teraplikasi dengan pembelajaran kesetaraan ini juga yang mempengaruhi bahwa masuk jam keseteraan itu sendiri hanya Hari Rabu, Sabtu dan Minggu pukul 19.00 - 21.00 WIB.

Untuk menghadapi faktor penghambat yang telah diketahui sebelumnya dalam program kewirausahaan terhadap perubahan perilaku kemandirian warga belajar paket $C$ di PKBM Al-Hikmah Sukodono Sidoarjo ini haruslah mendapat penanganan yang optimal dan serius guna menghindari terjadinya penurunan kualitas dan efektifitas program kewirausahaan baik pra koperasi maupun berbasis life skill. Berdasarkan pada pengertian (Depdiknas, 2005) dimana solusi adalah merupakan suatu bentuk upaya dalam memecahkan masalah, penyelesaian dan jalan keluar untuk menghadapi permasalahan atau hambatan yang menghambat jalannya proses pelaksanaan program kewirausahaan 
terhadap perubahan perilaku kemandirian warga belajar kelompok belajar paket $\mathrm{C}$ di PKBM Al-Hikmah Sukodono Sidoarjo.

Dari situlah langkah-langkah dan bentuk penanganan yang serius mengenai solusi yang diambil dalam memecahkan masalah atau jalan keluarnya dan itu pula harus disesuaikan dengan faktor penghambatnya. Diantaranya selain warga belajar dapat mendirikan usaha sendiri sebelumnya warga belajar di magangkan dari pihak PKBM bekerja sama dengan instansiinstansi terkait. Selain itu juga dalam waktu proses pembelajaran harus mencari waktu yang tepat agar dalam waktu program tidak berbenturan dengan waktu bekerja ataupun waktu pembelajaran kesetaraan, selalu mengadakan pertemuan kepada warga belajar, tutor/ nara sumber, masrayakat, pemerintah, dan pihak yang terkait untuk memberikan gambaran program kegiatan yang dilaksanakan, dengan demikian nantinya dapat memperlancar proses pelaksanaan program kewirausahaan terhadap perubahan perilaku kemandirian warga belajar kelompok belajar paket $\mathrm{C}$ di PKBM Al-Hikmah Sukodono Sidoarjo.

Dalam setiap dilaksanakannya suatu kegiatan pembelajaran pastinya dibutuhkan sebuah ukuran untuk menentukan suatu keberhasilan yang akan dicapai dalam program kewirausahaan terhadap perubahan perilaku kemandirian warga belajar paket $\mathrm{C}$ di PKBM Al-Hikmah Sukodono Sidoarjo yang nantinya dapat dijadikan sebagai standart tolak ukur dalam menentukan keberhasilan dan kualitas program atau rencana program selanjutnya. Salah satu standart keberhasilan yang ada dalam program kewirausahaan terhadap perubahan perilaku kemandirian warga belajar kelompok belajar paket $\mathrm{C}$ ini adanya perubahan yang ada pada keluaran (out put) dari warga belajar itu sendiri yang dilakukan setelah melalui proses pendampingan dan pembelajaran dalam jangka waktu tertentu.

Menurut Soemanto (1999), ada enam cirri manusia yang memiliki sikap kewirausahaan yaitu: mempunyai kemauan keras untuk mencapai tujuan dan kebutuhan hidupnya; mempunyai keyakinan yang kuat yang ada pada dirinya sendiri; jujur dan tanggung jawab; mempunyai ketahanan fisik dan mental; tekun dan ulet dalam bekerja dan berusaha; serta memiliki pemikiran yang konstruktif dan kreatif.

Dalam program kewirausahaan terhadap perubahan perilaku kemandirian warga belajar kelompok belajar paket $\mathrm{C}$ di PKBM Al-Hikmah Sukodono Sidoarjo ini sudah sangat efektif dan mencapai tujuan yang diinginkan sesuai dengan pendapat 6 ciri manusia yang memiliki sikap kewirausahaan. Hal ini sebagaimana telah dijelaskan oleh ketua penyelenggara program bahwa seteleh mengikuti program kewirausahaan pra koperasi warga belajar sudah mampu menguasai dan memahami serta mempraktekkan materi yang telah disampaikan serta memiliki aspek sikap kewirausahaan yang terpenting seperti yang telah disebutkan diatas yaitu percaya diri untuk bisa melakukan sesuatu hal. Setelah program ini selesai warga belajar dapat membuka usaha sendiri, dan bisa membuka lapangan pekerjaan bagi warga belajar lainnya, serta bisa meningkatkan kualitas hidupnya yang awalnya buruh menjadi karyawan kantor.

Disini tutor/ nara sumber serta ketua penyelenggara program merupakan orang terdekat bagi warga belajar di satu sisi banyak warga belajar yang merupakan pendatang dari daerah lain yang jauh dari orang tua. Warga belajar diharapkan dapat merubah perilaku yang dulunya bergantung sekarang menjadi mandiri ini dikarenakan banyaknya tuntutan dalam dunia kerja ataupun dunia era modern seperti saat ini.

Jika tingkat keberhasilan program kewirausahaan terhadap perubahan perilaku kemandirian warga belajar kelompok belajar paket C di PKBM Al-Hikmah Sukodono Sidoarjo di prosentasekan adalah sebagai berikut :

Jumlah warga belajar yang mengikuti program kewirausahaan adalah 20 orang per angkatan yang peneliti amati dan yang mampu mandiri ada 15 orang (dengan daftar nama terlampir) jadi prosentase warga belajar yang mengikuti program kewirausahaan dan ada perubahan perilaku kemandirian adalah sebagai berikut :

$$
\frac{15}{20} \times 100=75 \%
$$

Jadi prosentase keberhasilan dari program kewirausahaan ini ada $75 \%$ 


\section{Learning Community: Jurnal Pendidikan Luar Sekolah, 4 (1), Maret 2020 - 56}

Frimha Purnamawati

Dari tingkat keberhasilan pada program kewirausahaan ini berjumlah 15 warga belajar, sedangkan 5 warga belajar lainnya belum seperti mereka. Dalam hal ini bukan berarti mereka tidak berhasil untuk mengaplikasikan apa yang diperoleh saat mengikuti program kewirausahaan tersebut, melainkan masih adanya rasa kurang percaya diri atas kemampuan yang dimiliki untuk diaplikasikan pada lingkungannya. Meskipun mereka masih mempunyai rasa kurang percaya diri akan tetapi warga belajar tersebut sudah memiliki bekal ketrampilan yang telah diikuti.

\section{SIMPULAN}

Program Kewirausahaan yang diadakan oleh PKBM Al-Hikmah Sukodono yaitu program kewirausahaan pra koperasi. Materi yang disampaikan adalah bagaimana cara berwirausaha serta materi keterampilan yang terdiri dari menjahit, komputer, anyaman rotan, fotografi, kecantikan (salon) dan mengemudi mobil. Dana yang diberikan berupa modal awal yang nantinya wajib dikembalikan untuk dijadikan dana bergulir. Pengembalian dana dipercayakan pada 1 orang karyawan PKBM Al-Hikmah Sukodono Sidoarjo. Pengembalian dana bisa dilakukan secara langsung dan bisa dilakukan secara dicicil. Selain itu terdapat faktor pendukung dan penghambat dalam program kewirausahaan, Dari hasil adanya program kewirausahaan ini dapat berdampak positif tentunya bagi warga belajar yang telah mengikutinya. Disini dapat menunjukkan adanya perubahan perilaku kemandirian setelah mengikuti kegiatan program kewirausahaan baik kewirausahaan prakoperasi maupun kewirausahaan berbasis life skill. Dari 20 warga belajar terdapat 15 warga belajar yang mengalami perubahan perilaku kemandirian yaitu berupa penerapan keterampilan - keterampilan yang diperoleh di PKBM Al-Hikmah Sukodono Sidoarjo pada dunia usaha mandiri. Hal ini dapat dicontohkan warga belajar membuka usaha konveksi, usaha foto pre wedding, usaha percetakan foto, usaha jual pulsa, usaha sembako, usaha jual buah-buahan, usaha jual jamu, usaha makanan ringan dsb serta meningkatnya kualitas warga belajar yang awalnya buruh setelah mengikuti keterampilan komputer dan mengemudi mobil dan mendapatkan sertifikat warga belajar tersebut menjadi karyawan kantor. Perubahan perilaku kemandirian itulah yang membuat program kewirausahaan diakatakan berhasil dengan tingkat prosentase $75 \%$.

Berdasarkan kenyataan bahwa berkaitan dengan adanya penelitian diatas, maka ada beberapa saran yang diajukan sebagai berikut :

1. Program kewirausahaan terhadap perubahan perilaku kemandirian warga belajar kelompok belajar paket $\mathrm{C}$ di PKBM Al-Hikmah Sukodono Sidoarjo ini sudah berjalan akan tetapi agar supaya lebih baik hendaknya harus dipertahankan program tersebut dan perlu ditingkatkan lagi dengan cara mengembangkan atau menyusun program-program kegiatan yang lain yang hampir sama esensinya guna mencapai keluaran (out put) warga belajar yang siap di dunia usaha dan dunia kerja serta memiliki bekal pengetahuan, wawasan dan keterampilan yang dapat diaplikasikan.

2. Bagi penyelenggara untuk lebih meningkatkan program kewirausahaan berbasis life skill. Maka lebih baik apabila program semacam ini dapat diadakan disetiap daerah khususnya untuk warga belajar paket C sekarang ini agar siap pada persiapan dunia kerja dan dunia usaha di era globalisasi dan diadakan sanksi kepada warga belajar jika terlambat mengembalikan cicilan modal. Pemberian sanksi tersebut diberikan agar warga belajar yang mengikuti program kewirausahaan disiplin dalam tata tertib kewirausahaan pra koperasi.

3. Bagi warga belajar paket $\mathrm{C}$ yaitu dengan menggalakkan promosi dengan berbagai media seperti pembutan selebaran, pamphlet, dan brosur agar usaha yang diciptakan dapat lebih dikenal lagi oleh masyarakat luas, pengemasan produksi yang diciptakan lebih bisa dikemas dengan merek dan patokan harga yang bisa mendapatkan laba untuk meningkatkan penghasilan dan kesejahteraan warga belajar paket $\mathrm{C}$. 
Learning Community: Jurnal Pendidikan Luar Sekolah, 4 (1), Maret 2020 - 57

Frimha Purnamawati

\section{DAFTAR PUSTAKA}

Dessler, Garry. (2008). Manajemen Sumber Daya Manusia. Jakarta: Prenhallindo

Arikunto, Suharsimi. 2002. Prosedur Penelitian Suatu Pendekatan Praktek.Jakarta: PT. Asdi Mahasatya

Kamil, Mustofa Prof.Dr. H. 2010. Model Pendidikan dan Pelatihan (Konsep dan Aplikasi). Bandung: Alfabeta
Sugiyono. 2009. Metode Penelitian Kuantitatif Kualitatif dan R\&D. Bandung: Alfabeta Suryana. 2001. Kewirausahaan. Jakarta: Salemba Empat.

Moleong, Lexy J. (2005) Metodologi Penelitian Kualitatif, Penerbit PT Remaja Rosdakarya. Offset, Bandung.

Riyanto. Yatim. Metodologi Penelitian Pendidikan. Surabaya: SIC. 